\title{
The earnings of immigrants and the quality adjustment of immigrant human capital
}

\author{
Mesbah Fathy Sharaf
}

\section{Correspondence:}

Mesbah.sharaf@concordia.ca Department of Economics,

Concordia University, Montreal, Canada

\section{Springer}

\begin{abstract}
The quality dimension of immigrant human capital has received little attention in the economic assimilation literature. The objective of this paper is to demonstrate how human capital acquired in different source countries may be adjusted according to its quality in the Canadian labor market. This is achieved by deriving quality-adjustment indices using data from the 2001 Canadian census. These indices are then used to examine the role of schooling quality in explaining differential returns to schooling and over-education rates by country-of-origin. The key finding is that accounting for schooling quality virtually eliminates native-immigrant gaps in returns to schooling and the incidence of over-education. The quality of human capital is important for understanding the economic integration of immigrants.
\end{abstract}

JEL Codes: F22; I2; J15; J31

Keywords: Economic Integration; Returns to Schooling; Over-education; Schooling Quality; Human capital; Immigrants

\section{Introduction}

Recent empirical evidence reveals that the quality of human capital plays an important role in accounting for differences in growth rates across countries (e.g. Hanushek and Kimko, 2000; Schoellman, 2012). However, measuring the quality of human capital remains an empirical challenge, given that it is not directly observed.

The principal objective of this paper is an explicit derivation of quality adjustment indices which modify the human capital of immigrants acquired from different countries, using information on their earnings in the Canadian labor market. The derived indices are then used to examine the role of schooling quality in explaining differential returns to schooling and over-education rates by nativity.

The derivation of the quality-adjustment indices is based on the following two steps. First, the returns to immigrants' foreign-obtained schooling are estimated, using an augmented version of the Mincerian earnings function. Supporting evidence is then provided of the ability of these estimated returns to measure the schooling quality of their corresponding country of origin. Second, the estimated country-specific returns to schooling are used to estimate a schooling quality production function whose fitted returns are then used to derive a quality adjustment index for each country of origin.

An important finding of this paper is that accounting for schooling quality virtually eliminates the native-immigrant gaps in the returns to schooling and the incidence of over-education. This implies that when human capital is measured by years of

(C) 2013 Sharaf; licensee Springer. This is an Open Access article distributed under the terms of the Creative Commons Attribution License (http://creativecommons.org/licenses/by/2.0), which permits unrestricted use, distribution, and reproduction in any medium, provided the original work is properly cited. 
schooling alone, as is standard in the literature, some of the discrepancy in the labor market outcomes between immigrants and the native-born arise from differences in the quality of human capital between the host and home countries. In sum, the findings of this paper confirm that quality of human capital is important for understanding the economic integration of immigrants.

This paper proceeds as follows. In Section 2 there is a brief description of the background, followed, in Section 3, with a detailed description of the method of evaluating quality adjustment indices. A description of the sample and data to be used is carried out in Section 4. Section 5 presents and discusses the results and Section 6 summarizes the conclusion.

\section{Background}

\subsection{Returns to schooling and over-education}

The labor market performance of immigrants compared to the native-born has been the subject of intensive research (e.g. Galarneau and Morissette, 2004; Li et al., 2006; Green et al., 2007; Wald and Fang, 2008). Earnings and occupational placement have been commonly used to assess the degree of economic integration of immigrants. A key factor directly related to this integration process is the quality of foreign-acquired human capital brought into the host country (Friedberg, 2000; Chiswick and Miller, 2009; Piracha et al., 2012).

There are two empirical regularities which emerge from the literature on the assimilation of immigrants into a host country's labor market. The first is that foreignobtained schooling is discounted in the host country's labor market. This is reflected by a lower return to an immigrant's education compared with the education of a corresponding native (see e.g. Chiswick, 1978; Baker and Benjamin, 1994; Friedberg, 2000; Alboim et al., 2005; Chiswick and Miller, 2008). The second regularity is that overeducation rate is, on average, higher among immigrants than it is among corresponding natives (see e.g. Li et al., 2006; Kler, 2007; Green et al., 2007; Galarneau and Morissette, 2008; Wald and Fang, 2008; Nielsen, 2011) ${ }^{1}$.

The first of these two regularities was established in the seminal paper on economic assimilation of foreign-born males in the U.S. labor market by Chiswick's (1978) using 1970 census data. Chiswick (1978) estimated that an extra year of schooling for a foreign-educated worker raises earnings by 5.7 percent, compared with 7.2 percent for a corresponding American-born. Moreover, the return to schooling for immigrants from English-speaking countries is 6.6 percent, whereas for other immigrants it is 5.2 percent. Similar results hold in the Australian labor market (Beggs and Chapman, 1988), in the Canadian (Baker and Benjamin, 1994; Alboim et al. 2005; Reitz, 2001; Ferrer and Riddell 2008; Wald and Fang, 2008), for the U.K. (Shields and Price, 1998), for Israel (Friedberg, 2000) and for Sweden (Nordin, 2011).

An example of the second regularity, namely over-education, is Li et al. (2006) who find that from 1993 to 200152 percent of immigrants into Canada since 10 years or less were over-educated, compared with 28 percent of corresponding Canadians. Similar results are reported by, for example, Galarneau and Morissette (2008), Wald and Fang (2008) and Sharaf (2013) for Canada, Nielsen (2011) for Denmark, Lindley and Lenton (2006) for the U.K, Green et al. (2007) and Kler (2007) for Australia. 
Several explanations have been suggested for a lower relative return to schooling for foreign-acquired education and a higher incidence of over-education among immigrants. These include lower quality of foreign schooling (Chiswick and Miller, 2009), "country-specific aspects" of the knowledge acquired in schools (Chiswick, 1978), incompatibility of foreign-obtained schooling with the requirements of the host country labor market (Friedberg, 2000), lack of host country-specific human capital such as language proficiency (Alboim et al., 2005).

\subsection{Schooling quality}

Given that education quality is not directly observed, previous studies mostly used two main methods to infer it. The first approach uses student outcomes such as scores on internationally standardized tests like the Programme for International Student Assessment (PISA) as a direct measure for schooling quality. The second approach involves estimating an education quality production function and relating educational inputs, such as the pupil-teacher ratio and expenditures per pupil to an educational outcome. For example, Lee and Barro (2001) estimated a schooling quality production function that relates a set of educational outcomes such as international test scores, repetition and dropout rates to a set of family inputs and school resources.

In addition to the use of educational inputs to measure education quality, several studies have used student scores in international achievement tests to infer the quality of the educational system (e.g. Hanushek and Kimko, 2000; Sweetman, 2004; Chiswick and Miller, 2010). For example, Hanushek and Kimko (2000) used country scores from international achievement tests to construct measures of the average quality of the labor force of each country, which were then used to explain cross-country differences in growth rates. Other studies (e.g. Chiswick and Miller, 2010) have used the PISA, an international evaluation of 15-year-old school pupils' scholastic performance conducted every three years by the Organization for Economic Co-operation and Development (OECD), as a proxy for the average quality of schooling.

Though international test scores and educational resources have been commonly used to measure schooling quality, they suffer from several shortcomings that affect their validity and accuracy. For instance, several studies found weak correlation between test scores of students and consequent labor market outcomes. The test scores also suffer from selectivity bias and difficulties in standardizing the tests (Betts, 1995). In addition these test scores are not available for many developing countries. For a more comprehensive review of the limitations of these measures see, for example, Betts (1995), Ladd and Loeb (2012).

This paper adds to the existing literature on cross-country differences in educational quality by incorporating the idea that the earnings of foreign-educated immigrants in the same host labor market can be used to measure the average quality of schooling of each home country. The idea of using information on the labor market outcomes of foreign-educated immigrants to infer the quality of human capital in their countryof-origin derives from Hendricks (2002). Hendricks (2002) used the average labor earnings of immigrants, with identical measured skills in the US labor market, to estimate unmeasured human-capital endowments across countries. In a similar fashion, Mattoo et al. (2008) used the probability of placement of highly educated immigrants in skilled 
jobs in the U.S. labor market as a measure of the "average quality" of human capital of the source country. The authors found that the occupational attainment of immigrants in the U.S. labor market is largely affected by the characteristics of the source country that influence the quality of human capital such as the amount of educational resources devoted to schooling. They found that immigrants from source countries with low schooling quality are more likely to end up working in unskilled jobs than immigrants from source countries with better schooling quality. In a recent study, Schoellman (2012) estimated the return to schooling of immigrants in the US labor market and used these returns as a measure of schooling quality of the source countries. Schoellman (2012) demonstrated that cross-country differences in education quality are as important as cross-country differences in the quantity of schooling in accounting for differences in output per worker across countries.

The novelty of the present paper is its explicit derivation of quality adjustment indices which adjust human capital for cross-country differences in schooling quality. The derived indices are then used to examine the role of schooling quality in explaining differential returns to schooling and over-education rates by nativity.

\section{Method}

The empirical exercise of the current study could be summarized as follow: First, the returns to foreign-obtained schooling are estimated. Several robustness checks are then undertaken which provide evidence as to the validity of the estimates to measure schooling quality. Second, the estimated returns to schooling are used to derive schooling quality adjustment indices. Third, the evidence on the differential over-education rates and returns to schooling by nativity is then investigated.

\subsection{Estimating the return to schooling}

The first step in the analysis is to estimate the returns to foreign-obtained schooling, which are used to measure schooling quality for each country-of-origin. The method used here is an application of the idea developed by Card and Krueger (1992) who used the cross-state returns to the schooling of migrants to measure the schooling quality of states. The idea was also applied to cross-country comparisons by: Betts and Lofstrom (2000); Bratsberg and Terrell (2002); Sweetman (2004); Chiswick and Miller (2010), and Schoellman (2012).

Returns to foreign-obtained schooling are estimated using an augmented Mincerian earnings function:

$$
\ln \left(W_{i}^{j}\right)=a^{j}+\beta^{j} S_{i}^{j}+X_{i}^{j} \varphi+\varepsilon_{i}^{j}
$$

Equation 1 allows the logarithm of the weekly wage of the $i^{\text {th }}$ immigrant from the $\dot{j}^{\text {th }}$ country $\left(i=1,2, \ldots \ldots, n_{j} ; j=1,2, \ldots \ldots, m, \sum_{j} n_{j}=n\right)$ to be determined by: a countryspecific fixed effect, $\alpha^{j}$, total years of schooling, $S_{i}^{j}$, of immigrant $i$ from country $j$ times a country-specific return to schooling, $\beta^{j}$, a row vector of common observed covariates,

$X_{i}^{j}$, times a column vector of corresponding coefficients, $\varphi$, and a stochastic error $\varepsilon_{i}^{j}$. The control variables included in $X_{i}^{j}$ are: potential experience, measured by age minus years of schooling minus 6, three indicators for marital status (single, married and separated), four indicators for cohort fixed effects (1960-69, 1970-79, 1980-89, 1990-2000), 
ten indicators for provincial fixed effects and two indicators for language proficiency. Mother tongue was used in the regression analysis rather than ability to speak English or French since the former is exogenous and not affected by an individual's ability to learn a new language which may be positively correlated with schooling quality (Sweetman, 2004). All estimation and descriptive statistics are population weighted using the sampling weight provided in the census.

\subsection{Schooling quality adjustment indices}

The country-specific returns to foreign-obtained schooling are used to estimate an education quality production function similar to that of Lee and Barro (2001), and Bratsberg and Terrell $(2002)^{2}$. A typical schooling quality production function relates a schooling quality measure to a set of educational inputs as follow:

$$
Q=f(P, I)+\varepsilon
$$

where $Q$ denotes schooling quality, $P$ represents parental characteristics, $I$ represents educational resources and $\varepsilon$ captures unmeasured factors affecting schooling quality. In a more technical term, equation 2 can be specified as follow

$$
R^{j}=\alpha^{j}+\beta_{1} P^{j}+\beta_{2} I^{j}+\varepsilon^{j}
$$

where $j$ indexes countries, $R^{j}$ denotes the country of origin-specific return to schooling, as a measure of schooling quality, $P^{j}$ denotes a set of parental factors, $I^{j}$ denotes a vector of educational resources and $\varepsilon^{j}$ captures country-specific unmeasured factors affecting schooling quality.

In the analysis, educational resources are measured by the pupil-teacher ratio in primary schools, log of real government educational expenditure per pupil in primary schools, number of school days per year at primary schools (as a measure of the intensity of education), and the $\log$ of real salary of primary school teachers (as a measure of teachers' quality). Data on educational resources are obtained from Lee and Barro (1997). In addition to school resources, it has been shown that the academic achievement of a student is largely affected by non-school factors such as family background. Several studies have shown that family background such as the parent's education and income level are important determinants of the educational outcomes of their children (Psacharopoulos and Woodhall, 1985). Parental factors are measured by the log of real per capita GDP (as a proxy for family income) obtained from Penn World Tables (Heston et al., 2011), and average years of primary schooling of adults aged 25 and above (as a proxy for the family education) obtained from Barro and Lee $(2010)^{3}$. To better capture the attributes of the educational system and parental factors that were prevailing at the time immigrants undertook their education, lagged data from the period 1975 to 1980 are used $^{4}$.

The fitted values of the returns to schooling of each country of origin, which are obtained from the schooling quality production function, are then used to derive schooling quality adjustment indices which convert years of schooling from different countries into Canadian terms. Consider two workers, an immigrant from country $j$ and a native-born, who are identical in observed characteristics $X_{i}^{j}=X_{i}^{c a n}$, apart from schooling level, and earn the same wage net of country fixed effects. Since the countryof-origin fixed effect, $\alpha^{j}$, is potentially affected by selection of immigrants based on 
unobserved characteristics, or may be affected by other factors unrelated to schooling quality, the intercept, $\alpha^{j}$, in equation (1) is discarded to focus only on the countryspecific return to schooling, $\hat{\beta}^{j}$. This permits equation (1) to be estimated in re-written form:

$$
\ln \hat{W}^{j}=\hat{\beta}^{j} S_{i}^{j}+X_{i}^{j} \hat{\phi}=\hat{\beta}^{c a n} S_{i}^{c a n}+X_{i}^{c a n} \hat{\varphi}=\ln \hat{W}^{c a n}
$$

Thus

$$
\hat{\beta}^{j} S_{i}^{j}=\hat{\beta}^{c a n} S_{i}^{c a n}
$$

and the schooling level of the immigrant is equivalent to the schooling level of the Canadian-born. In other words, years of foreign-obtained schooling can be transformed into Canadian-equivalent years using the relative return to schooling as

$$
\bar{s}_{i}^{j}=\frac{\hat{\beta}^{j}}{\hat{\beta}^{c a n}} S_{i}^{j}
$$

In equation (5), $\bar{s}_{i}^{j}$ denotes total years of schooling of immigrant $i$ from country $j$ expressed in equivalent Canadian terms, called "quality-adjusted schooling”. The term $\frac{\hat{\beta}^{j}}{\hat{\beta}^{\text {can }}}$ is a country-specific adjustment index that converts foreign-obtained years of schooling into Canadian terms and $S_{i}^{j}$ is the quality unadjusted years of schooling ${ }^{5}$.

\subsection{Over-education}

The classification of a worker as over-educated is based on the realized match method. According to this method an individual is considered to be over-educated if his educational attainment is greater than a reference measure for the educational requirements of the job (Hartog, 2000; Chiswick and Miller, 2008). This paper uses the modal years of schooling of Canadian-born workers to determine required years of schooling in each of the 508 occupations identified in the census. As is standard, a job-education mismatch is measured by $O_{i j}$,

$$
O_{i j}=S_{i j}^{c}-S_{j}^{r}
$$

where $O_{i j}$ is an indicator variable as to whether a worker is over-educated or not, $S_{i j}^{c}$ represents total years of schooling completed by worker $i$ working in job $j$, and $S_{j}^{r}$ represents years of schooling required by job $j$. A worker is considered to be overeducated if $S_{i j}^{c}>S_{j}^{r}$.

\section{Data}

The empirical analysis uses data from the confidential master file of the 2001 Canadian Census of Population. The merit of the census data is that it includes a large sample of immigrants from a wide range of countries, along with information on a comprehensive set of demographic and labor market variables for a nationally representative sample of individuals ${ }^{6}$. In addition, the census file includes detailed occupational codes for the job held by employed individuals at the time of an interview. The occupational coding system is based on the 1980 Standard Occupational Classification. This was used to 
determine the years of schooling required in each occupation and hence determine the prevalence of over-education.

The analysis is restricted to males, aged 24 to 65 years who are paid workers and work full time. In addition, the analysis excludes individuals with missing values on relevant variables. Source countries with observations less than 500 immigrants are also excluded from the sample. These restrictions produce a sample of 5,117,249 Canadians and 680,107 immigrants from 78 source countries. To control for the possibility that an immigrant may have obtained some Canadian education after immigration, the analyses is restricted to immigrants whose age at immigration is at least 24 years old as a baseline specification. This threshold was raised to 30 years old as a robustness check on the results. The rationale behind this exclusion is that any post immigration investment in education is likely to raise the return to foreign-obtained schooling and hence will bias upward the estimate of the source country schooling quality (Duleep and Regets, 1999).

Table 1 reports the characteristics of the baseline sample that is used in the analysis. Immigrants represent 12.3 percent of the sample. On average, immigrants are older,

Table 1 Descriptive statistics (Mean)

\begin{tabular}{|c|c|c|c|}
\hline Variable & Whole population & Natives & Immigrants \\
\hline Age & 40.37 & 39.67 & 45.81 \\
\hline Potential experience & 20.7 & 20.15 & 25.14 \\
\hline Years of schooling & 13.66 & 13.52 & 14.66 \\
\hline Wages \& salaries & $43,322.85$ & 43,694 & 40,439 \\
\hline Single & 32.63 & 35.68 & 9.64 \\
\hline Separated & 10.78 & 11.19 & 7.89 \\
\hline Married & 56.07 & 52.63 & 81.85 \\
\hline New found land & 1.78 & 2 & 0.17 \\
\hline Prince Edward & 0.48 & 0.54 & 0.05 \\
\hline Nova Scotia & 3.11 & 3.46 & 0.59 \\
\hline New Brunswick & 2.69 & 3.01 & 0.32 \\
\hline Quebec & 25.53 & 27.20 & 13.18 \\
\hline Ontario & 36.26 & 33.33 & 57.72 \\
\hline Saskatchewan & 3.06 & 3.39 & 0.69 \\
\hline Alberta & 11.16 & 11.52 & 8.51 \\
\hline British Columbia & 11.93 & 11.33 & 16.28 \\
\hline Manitoba & 3.67 & 3.86 & 2.35 \\
\hline English/French is mother tongue & 87.54 & 95.82 & 27.83 \\
\hline Working in unskilled occupations & 74.56 & 75.44 & 68.69 \\
\hline Immigration period 1990-2001 & & & 53.88 \\
\hline Immigration period 1980-1989 & & & 22.80 \\
\hline Immigration period 1970-1979 & & & 17.57 \\
\hline Immigration period 1960-1969 & & & 5.76 \\
\hline Observations & $5,797,356$ & $5,117,249$ & 680,107 \\
\hline
\end{tabular}

Source: Canadian 2001 census. With the exception of age, years of schooling, wages \& salaries and potential total experience which are continuous variables, the mean of all other variables represent the percentage of individuals belonging to each sub-category. All statistics are weighted using the sampling weights available in the census. 
more educated, have more work experience and are more likely to be married than the native-born ${ }^{7}$.

About one quarter of the immigrants reported English or French as their mother tongue. Immigrants are concentrated in four provinces; Ontario (58 percent), British Columbia (16.3 percent), Quebec (13.2 percent) and Alberta (8.5 percent). 53.88 percent of the immigrants arrived to Canada during the period 1990-2001, 22.8 percent immigrated during 1980-1989, 17.57 percent during 1970-1979 and 5.76 percent during 1960-1969.

India is the source of the largest percentage of immigrant males (8.73 percent) in the baseline sample, followed by United Kingdom (7.8 percent), China (7.75 percent), Philippines (5.49 percent), Hong Kong (4.42 percent), United States of America (3.80 percent) and Poland (3.67 percent).

\section{Results}

\subsection{Baseline estimation results}

Though not reported and are available upon request, estimates from the earnings function reveal the discounting of foreign-obtained schooling in the Canadian labor market. In particular, an extra year of Canadian schooling raises earnings by 7.06 percent, while the average return to a foreign-obtained year of schooling is estimated at 5.90 percent. Results also show wide variation in the returns to schooling across source countries (Standard deviation $=1.8$ ), with a general conclusion that the value of a year of schooling in the Canadian labor market depends on its origin. Results also show that the returns to schooling for most of the source countries are lower than the Canadian return of 7.06 percent. These results are consistent with the findings of earlier studies on the discounting of foreign-obtained schooling in the Canadian labor market (see for e.g. Baker and Benjamin, 1994; Alboim et al., 2005) and are also consistent with evidence for immigrants to U.S. (e.g. Chiswick, 1978; Friedberg, 2000). Nicaragua is the source country with the lowest return to schooling, estimated at 1.66 percent, followed by the Dominican Republic (2.4 percent), El Salvador (2.9 percent) and Syria (3.1 percent). For source countries with a substantial number of immigrants, the returns to schooling were 6.7 percent for China and India, Philippines (4 percent), United Kingdom (6.5 percent) and Poland (4.6 percent). On the upper segment of the returns distribution, the country-specific returns to schooling from 12 countries are higher than the Canadian return. These include Switzerland (11.5 percent), South Africa ( 9 percent), Hong Kong (8.7 percent), Denmark (8.3 percent), Belgium (8.1 percent), France (7.6 percent), Malaysia (7.5 percent), Australia (7.3 percent), Czechoslovakia (7.2 percent), Sri Lanka (7.2 percent), Hungary (7.2 percent) and Israel (7.1 percent $)^{8}$. These results are consistent with the empirical evidence on how the national origin of an individual's education matters for its return in the host labor market (Friedberg, 2000; Bratsberg and Terrell, 2002; Sweetman, 2004; Chiswick and Miller, 2010).

\subsection{Robustness checks}

Several robustness checks are conducted to check the sensitivity of the estimated returns to schooling to sample selection restrictions and to model specification. For example, in a second specification, immigrants whose age at immigration was less than 
30 years, instead of 24, are excluded to reduce further any bias that may result from taking education in Canada. In a third specification, returns to schooling are allowed to vary by immigration cohort and in a fourth specification by occupational skill level (skilled and un-skilled). The 508 occupations identified in the census are grouped into skilled and un-skilled categories based on the educational requirement of each occupation; skilled if the occupation requires more than 12 years of schooling, otherwise it is classified as unskilled. Given the finding of several previous studies that foreign-acquired work experience has zero return in the Canadian labor market (e.g. Alboim et al. 2005). Another specification that was estimated includes only potential Canadian work experience. The country-specific returns to schooling from these different specifications were in general very close to the baseline model. For example, the difference between the Canadian return to schooling and the average returns to foreign obtained schooling was 1.16 percentage points, and ranges from 0.7 to 1.3 percentage points in the alternative specifications.

Figure 1, compares estimated returns to schooling in this paper with those obtained by Sweetman (2004). The goal of this comparison is to check whether there is something special about the 2001 Canadian census data set, or that it has particular features that may affect the empirical findings. As shown in Figure 1, the estimated country-specific returns to schooling in this paper are in general very close to those obtained using other data sets. Sweetman (2004) estimated the return to schooling of immigrants from a wide set of countries using a pooled sample of the 1986, 1991 and 1996 Canadian census. Part of the deviation of my estimated returns from the estimates of Sweetman (2004) may be attributable to differences in the sample selection and model specification.

\subsection{Supporting evidence for using returns to schooling to measure schooling quality}

It has been widely documented that immigrants from countries with high quality educational systems receive higher economic returns to foreign-acquired schooling than those from countries with low quality educational systems (Sweetman, 2004; Chiswick and

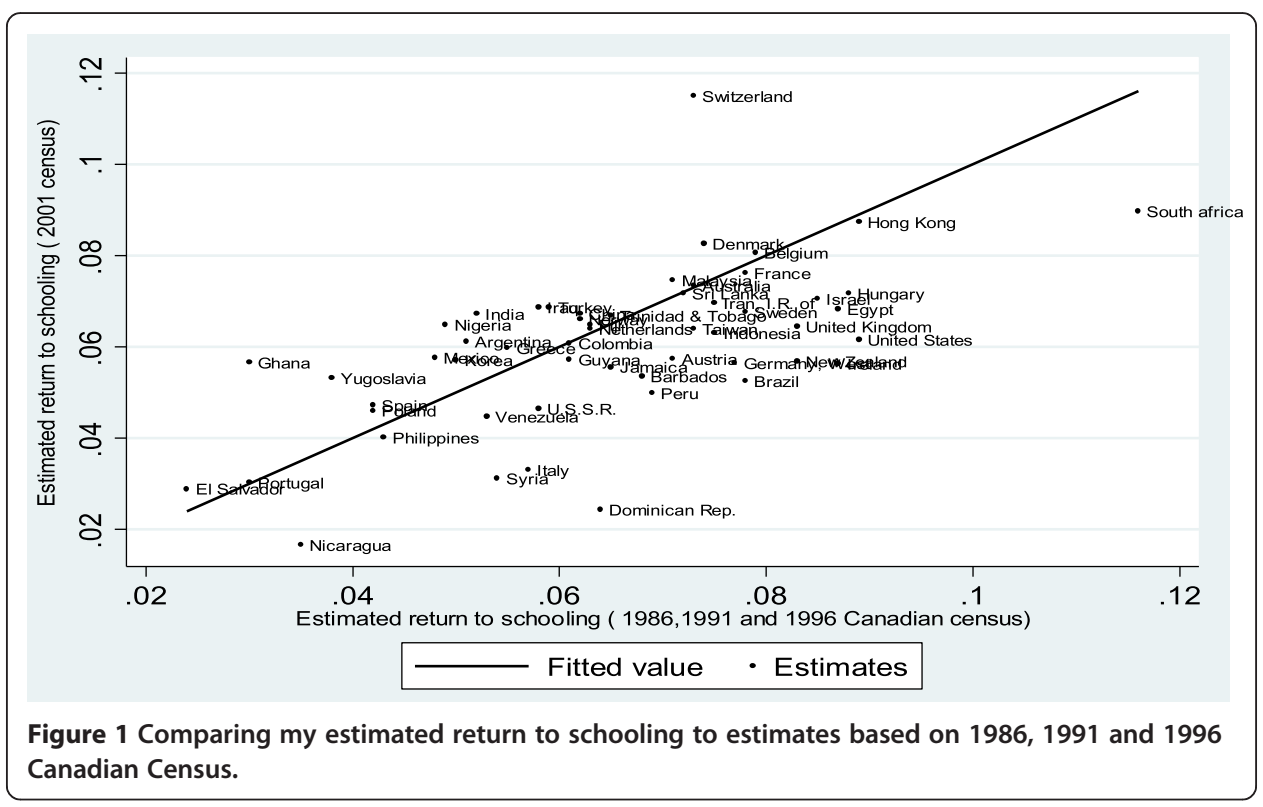


Miller, 2010). This implies that the return to schooling could be used as a "productivitybased" or a "market-based" measure of schooling quality (Bratsberg and Terrell, 2002).

To check the soundness of the returns to schooling as being a reasonable measure of schooling quality, these returns are compared to a set of widely used measures of schooling quality such as per-capita real GDP, international achievement test scores, dropout rate at primary schools as well as a set of educational inputs such as studentteacher ratio at primary schools, real government educational expenditure per pupil at primary schools, and real average salary of primary school teachers ${ }^{9}$.

Though not reported and are available upon request by the author, scatter plots show that on average, immigrants from source countries with higher per-capita real GDP earned higher returns on their foreign-obtained schooling than immigrants from countries with lower per-capita real GDP (correlation coefficient $=0.41$ ). In addition, the estimated country-specific returns to schooling are plotted against test scores from international achievement tests constructed by Hanushek and Kimko (2000). Hanushek and Kimko (2000) constructed a measure of the average schooling quality for a pool of countries based on student performance on international tests of academic achievement in mathematics and science conducted between 1965 and 1991 by two different international educational testing organizations. The Hanushek and Kimko (2000) constructed index is an educational outcome, widely used in the literature as a proxy for the average quality of schooling in each country. A positive correlation (correlation coefficient $=0.39$ ) is found between the estimated country-specific returns to schooling and international achievement test scores. In a recent study, Schoellman (2012) also found a positive correlation between the return to schooling of immigrants in the US labor market and another set of international test scores constructed by Hanushek and Woessmann (2012).

The estimated returns to schooling were also plotted against the dropout rate at primary schools, a commonly used proxy for schooling quality. Data on dropout rates are obtained from Lee and Barro $(1997)^{10}$. As expected, there is a negative correlation (correlation coefficient $=-0.54$ ) between the estimated return to schooling and the dropout rate at primary schools.

Additional evidence for the validity of schooling returns as a measure of schooling quality can be observed by plotting these estimated returns to schooling against several educational inputs that are directly related to schooling quality. To capture the attributes of the educational system better, the educational inputs data were lagged by 20 years to capture the time when immigrants were in school. These include the studentteacher ratio at primary schools, real government educational expenditure per pupil at primary schools, and real average salary of primary school teachers as a proxy for teacher quality. Data for these variables are obtained from Lee and Barro (1997).

On average, immigrants from countries with low pupil teacher ratios in primary schools earn a higher return on their foreign obtained schooling in the Canadian labor market (correlation coefficient $=-0.35$ ). In a similar fashion, estimated schooling returns are positively correlated (correlation coefficient $=0.48$ ) with $\log$ of real government educational expenditure per pupil at primary schools. Similar findings are reached when estimated returns to schooling are plotted against educational input data related to secondary schooling. These relationships are in general consistent with findings from other countries and data sets (e.g. Betts and Lofstrom, 2000; Bratsberg and Terrell, 2002; 
Sweetman, 2004; Chiswick and Miller, 2010). There was also a positive correlation between country-of-origin returns to schooling and teacher quality as measured by average salary (correlation coefficient $=0.52$ ) and average years in school (correlation coefficient $=0.35)^{11}$.

\subsection{Results for alternative specifications of the schooling quality production function}

The schooling quality production function is estimated under several model specifications to check the sensitivity of the results as shown in Table 2 . Model 1 includes only educational resources (pupil-teacher ratio and real government educational expenditure per pupil); model 2 includes the real salary of primary schools teachers in addition to the variables of model 1, while parental factors (real per capita GDP and average years of primary schooling) are added in models 3,4 and 5 .

Given that source countries have different sample sizes, the schooling quality production function is also estimated using weighted least squares, with the number of individuals from each source country used as a weight. The results from the weighted least squares are presented in model 5.

Results of model 5 show that pupil-teacher ratio has a negative relationship, though not statistically significant, with schooling quality. This is consistent with the expectation that smaller class size enhance quality of education. Results also show that both the length of the school term, as a measure of education intensity, and real government educational expenditure per pupil has a positive and statistically significant effect on schooling quality. The regression also included the average years of schooling as a measure of parental education level. This variable has the correct sign but is not statistically significant.

Table 2 Estimates for the schooling quality production function

\begin{tabular}{|c|c|c|c|c|c|}
\hline & $\begin{array}{l}\text { Model } \\
1\end{array}$ & $\begin{array}{l}\text { Model } \\
2\end{array}$ & $\begin{array}{l}\text { Model } \\
3\end{array}$ & $\begin{array}{l}\text { Model } \\
4\end{array}$ & Model 5 \\
\hline \multicolumn{6}{|l|}{ Educational inputs } \\
\hline \multirow[t]{2}{*}{ Pupil- Teacher ratio at primary schools } & -0.0372 & -0.0263 & -0.0247 & -0.0265 & -0.0340 \\
\hline & $(0.0279)$ & $(0.0468)$ & $(0.0305)$ & $(0.0470)$ & $(0.0317)$ \\
\hline \multirow{2}{*}{$\begin{array}{l}\text { Log real government educational expenditure per pupil at } \\
\text { primary schools }\end{array}$} & 0.346 & 0.389 & 0.447 & 0.336 & $0.550^{* * *}$ \\
\hline & $(0.239)$ & $(0.612)$ & $(0.424)$ & $(0.584)$ & $(0.159)$ \\
\hline \multirow[t]{2}{*}{ Number of school days per year at primary schools } & $0.0220^{*}$ & $0.0219^{*}$ & 0.0257 & 0.0220 & $0.0412^{* * *}$ \\
\hline & $(0.0123)$ & $(0.0123)$ & $(0.0162)$ & $(0.0228)$ & $(0.0120)$ \\
\hline \multirow[t]{2}{*}{ Log real salary of primary school teachers } & & 0.194 & & 0.611 & \\
\hline & & $(0.646)$ & & $(0.623)$ & \\
\hline \multicolumn{6}{|l|}{ Parental factors } \\
\hline \multirow[t]{2}{*}{ Average years of schooling } & & & 0.177 & 0.142 & 0.0607 \\
\hline & & & $(0.159)$ & $(0.165)$ & $(0.160)$ \\
\hline \multirow[t]{2}{*}{ Log real per capita GDP } & & & -0.296 & -0.527 & \\
\hline & & & $(0.435)$ & $(0.367)$ & \\
\hline \multirow[t]{2}{*}{ Constant } & 0.685 & -1.638 & 0.924 & -1.041 & $-6.314^{*}$ \\
\hline & $(3.217)$ & $(4.592)$ & $(4.586)$ & $(6.779)$ & (3.310) \\
\hline
\end{tabular}

Standard errors in parentheses, ${ }^{* *} p<0.01,{ }^{* *} p<0.05,{ }^{*} p<0.1$. Under Model 5 , schooling quality production function was estimated using weighted least squares, with the number of individuals from each source country is used as a weight. 
The estimated schooling quality production function was used to generate predicted values for the quality of schooling of each country of origin, which are then used to derive quality adjustment indices to control for cross-country schooling quality differences.

\subsection{Deriving schooling quality adjustment indices}

The derived country-specific quality adjustment indices are presented in Table 3, which shows considerable variation among source countries, ranging from 0.217 for Albania to 1.63 for Switzerland. Two useful reference countries with a considerable number of immigrants are Philippines (adjustment index $=0.57$ ) and Hong Kong (adjustment index $=1.24$ ). These adjustment indices can be interpreted as follows: On average, ten years of schooling from Philippines are equivalent to 5.7 years of Canadian schooling. Similarly, ten years of schooling from Hong Kong are equivalent to 12.4 years when expressed in Canadian terms.

\subsection{Returns to schooling using quality-adjusted data}

The Mincerian earnings function (1) is re-estimated using the quality-adjusted years of schooling. Years of schooling from different source countries are now expressed in the same Canadian quality units. Accordingly, if the quality adjustment indices accurately capture differences in schooling quality across countries, then the return to a year of quality-adjusted foreign-obtained schooling is expected to be close to the return to a Canadian year of schooling. In line with this a priori expectation, the average return to an extra year of quality-adjusted schooling of immigrants is 6.87 percent, which is very close to the Canadian return of 7.06 percent given above ${ }^{12}$. This is in contrast to 5.9 percent, obtained before the adjustment. The main conclusion from this exercise is that cross-country differences in schooling quality substantially explain the lower return to immigrant education in the Canadian labor market, and that the gap in returns to schooling nearly disappears once the quality of schooling is taken into account. By the same way, the lower return to immigrant schooling from many source countries, compared to the native-born return, is mainly due to the lower quality of foreignobtained schooling.

\subsection{Schooling quality and over-education prevalence by country of origin}

Schooling quality adjustment reveals that immigrant quality-unadjusted years of schooling, on average, overstate their earning capacity. Hence, an immigrant holding a job that requires less schooling than the immigrant has may incorrectly appear to be over-educated. Accordingly, the quality adjustment indices reported in Table 3 can be used to re-examine the evidence on the prevalence of over-education among immigrants.

Figure 2 depicts the aggregate incidence of over-education by nativity, using the quality-adjusted and unadjusted years of schooling.

It is evident from Figure 2 that the aggregate incidence of over-education, using quality unadjusted years of schooling, is higher among immigrants compared to native-born. Estimates show that 58.5 percent of immigrant males were over-educated in 2001 compared to 43.85 percent of the Canadian born. The high incidence of over-education among immigrants is in line with several previous studies. For instance, using the survey 
Table 3 Quality adjustment indices and over-education rates by country of origin

\begin{tabular}{|c|c|c|c|}
\hline \multirow[t]{2}{*}{ Country } & \multirow{2}{*}{$\begin{array}{l}\text { Quality } \\
\text { adjustment index }\end{array}$} & \multicolumn{2}{|c|}{ Over-education prevalence } \\
\hline & & Before Adjustment & After Adjustment \\
\hline Algeria & 1.185 & 80.05 & 94.4 \\
\hline Argentina & 0.869 & 63.06 & 35.52 \\
\hline Australia & 1.042 & 61.85 & 79.28 \\
\hline Austria & 0.815 & 62.65 & 35.34 \\
\hline Bangladesh & 0.898 & 74.73 & 63.71 \\
\hline Barbados & 0.761 & 47.29 & 14.33 \\
\hline Belarus & 0.668 & 72.65 & 10.86 \\
\hline Belgium & 1.146 & 62.62 & 90.73 \\
\hline Bosnia and Herzegovina & 0.756 & 54.61 & 20.72 \\
\hline Brazil & 0.746 & 63.95 & 18.65 \\
\hline Bulgaria & 0.807 & 71.1 & 41.45 \\
\hline Canada & 1.000 & 43.47 & 43.47 \\
\hline Chile & 1.256 & 67.79 & 94.39 \\
\hline China & 0.955 & 55.07 & 54.88 \\
\hline Colombia & 0.864 & 74.24 & 51.12 \\
\hline Croatia & 0.756 & 50.12 & 18.15 \\
\hline Cuba & 0.803 & 78.07 & 48.55 \\
\hline Czech Republic & 1.016 & 72.59 & 85.52 \\
\hline Czechoslovakia & 1.016 & 64.86 & 85.61 \\
\hline Denmark & 1.173 & 60.67 & 83.05 \\
\hline Egypt & 0.970 & 79.41 & 79.41 \\
\hline Fiji & 0.922 & 38.45 & 27.97 \\
\hline Finland & 0.626 & 52.31 & 2.46 \\
\hline France & 1.083 & 65.43 & 83.23 \\
\hline Germany & 0.801 & 60.36 & 32.61 \\
\hline Ghana & 0.804 & 66.79 & 34.51 \\
\hline Greece & 0.848 & 29.88 & 15.85 \\
\hline Grenada & 0.689 & 44.24 & 1.42 \\
\hline Guatemala & 0.778 & 46.3 & 23.36 \\
\hline Guyana & 0.814 & 50.15 & 22.73 \\
\hline Haiti & 0.678 & 54.29 & 7.82 \\
\hline Hong Kong & 1.241 & 54.71 & 90.1 \\
\hline Hungary & 1.019 & 61.63 & 81.41 \\
\hline India & 0.954 & 58.91 & 58.59 \\
\hline Indonesia & 0.896 & 73.78 & 58.46 \\
\hline Iran & 0.988 & 71.5 & 71.5 \\
\hline Iraq & 0.976 & 59.42 & 59.42 \\
\hline Ireland & 0.800 & 54.71 & 19.45 \\
\hline Israel & 1.002 & 54.83 & 78.31 \\
\hline Italy & 0.469 & 24.27 & 0 \\
\hline Jamaica & 0.790 & 41.33 & 11.7 \\
\hline Japan & 0.554 & 67.4 & 0.69 \\
\hline Korea, South & 0.811 & 69.96 & 47.73 \\
\hline
\end{tabular}


Table 3 Quality adjustment indices and over-education rates by country of origin (Continued)

\begin{tabular}{|c|c|c|c|}
\hline Malaysia & 1.061 & 60.96 & 78.78 \\
\hline Malta & 0.270 & 46.58 & 0 \\
\hline Mexico & 0.820 & 41.42 & 22.12 \\
\hline Morocco & 0.946 & 71.84 & 70.93 \\
\hline Netherlands & 0.909 & 65.89 & 52.1 \\
\hline New Zealand & 0.808 & 57.57 & 26.38 \\
\hline Nigeria & 0.921 & 81.06 & 67.45 \\
\hline Norway & 0.938 & 60.54 & 54.96 \\
\hline Pakistan & 0.756 & 67.13 & 34.28 \\
\hline Peru & 0.709 & 77.15 & 28.06 \\
\hline Philippines & 0.571 & 71.25 & 0.81 \\
\hline Poland & 0.653 & 68.52 & 5.27 \\
\hline Portugal & 0.430 & 10.75 & 0 \\
\hline Romania & 0.977 & 64.68 & 64.68 \\
\hline Russian Federation & 0.668 & 67.2 & 9.98 \\
\hline Singapore & 0.588 & 62.3 & 1.48 \\
\hline Slovakia & 1.016 & 73.1 & 86.98 \\
\hline South Africa & 1.274 & 64.54 & 97.24 \\
\hline Spain & 0.670 & 54.71 & 7.52 \\
\hline Sri Lanka & 1.019 & 52.46 & 72.74 \\
\hline Sudan & 0.588 & 69.43 & 3.44 \\
\hline Sweden & 0.960 & 64.92 & 64.92 \\
\hline Switzerland & 1.634 & 68.19 & 98.97 \\
\hline Syria & 0.443 & 62.75 & 0.35 \\
\hline Taiwan & 0.908 & 65.79 & 54.13 \\
\hline Trinidad and Tobago & 0.950 & 55.33 & 55.12 \\
\hline Turkey & 0.976 & 44.6 & 44.6 \\
\hline U.S.S.R & 0.661 & 68.51 & 11.80 \\
\hline UK & 0.917 & 58.03 & 44.52 \\
\hline Ukraine & 0.661 & 73.51 & 9.22 \\
\hline USA & 0.875 & 58.16 & 40.03 \\
\hline Venezuela & 0.635 & 74.09 & 4.88 \\
\hline Yugoslavia & 0.756 & 57.13 & 21.79 \\
\hline
\end{tabular}

Source: Author's calculations based on data from Canadian 2001 census. All results are weighted using the sampling weights available in the census.

of labor and income dynamics, Li et al. (2006) found that during the 1993-2001 period, 52 percent of recent immigrants to Canada-those in Canada for 10 years or less-were over-educated. Lindley and Lenton (2006) found that 63 percent of male immigrants to the U.K. are overeducated compared to 37 percent of male natives. In another study, Wald and Fang (2008) found that about 50 percent of the immigrants arriving between 1989 and 1997 were overeducated in 1999.

Another key result is that immigrants not only have a higher incidence of overeducation than their Canadian-born counterparts, but also a higher intensity of overeducation, measured in terms of years of surplus schooling above what is required by 


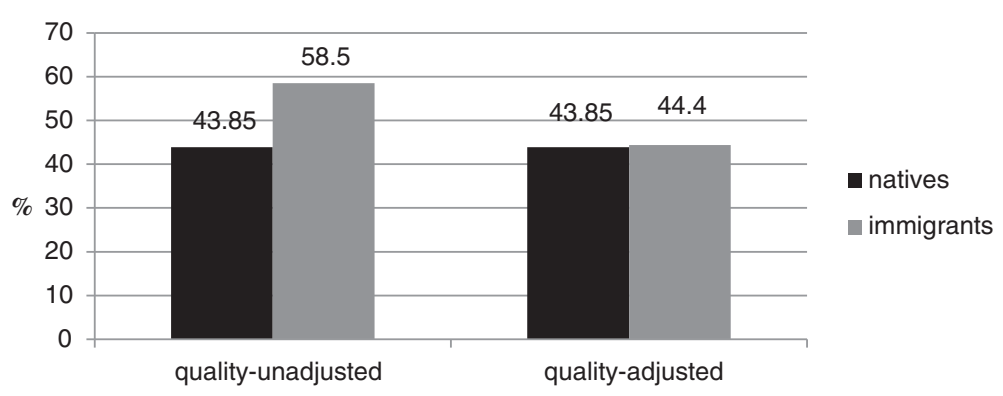

Figure 2 Over-education incidence among natives and immigrants.

the job. Estimates, using quality-unadjusted years of schooling, show that immigrant males have, on average, 3.6 (standard deviation $=2.28$ ) years of surplus schooling, compared to 2.82 years (standard deviation $=1.84$ ) for natives.

As previously mentioned, these differential over-education rates by nativity may be due to differences in schooling quality that are not captured by years of schooling alone. Accordingly, the objective now is to see how these aggregate over-education rates change when schooling quality is taken into account using the quality adjustment indices derived in the previous section.

The fundamental result from this quality adjustment exercise is that accounting for schooling quality virtually eliminates the native-immigrant gap in the incidence of over-education. In particular, estimates show that the incidence of over-education among immigrants, after adjusting for quality differences, becomes 44.4 percent, which is very close to the Canadian incidence of 43.85 percent. This is in contrast to 58.5 percent, obtained before adjusting for schooling quality. The intensity of over-education among immigrants declined, but only a little, from 3.6 to 3.39 after adjusting for quality differences. The general conclusion from these findings is that when the job-education mismatch is measured by years of schooling alone, as is standard in the literature, some of this apparent mismatch arises because of differences in schooling quality between the host and home countries.

\section{Conclusion}

This paper explicitly derives schooling quality adjustment indices to account for differences in cross-country schooling quality, using information on labor market earnings. The derived indices are used to explain the differential returns to schooling and overeducation rates by nativity.

The fundamental finding is that accounting for schooling quality virtually eliminates the native-immigrant gaps in the returns to schooling and in the incidence of overeducation. In particular, the return to an extra year of quality-adjusted schooling of immigrants is 6.87 percent, which is very close to the Canadian return of 7.06 percent. This is in contrast to 5.9 percent, obtained before the adjustment. Estimates also show that the incidence of over-education among immigrants, after adjusting for quality differences, is 44.4 percent, which is very close to the Canadian incidence of 43.85 percent. This is in contrast to 58.5 percent, obtained before adjusting for schooling 
quality. This implies that when human capital is measured by years of schooling alone, as is standard in the literature, some of the apparent labor market disadvantage of immigrants relative to natives arises due to differences in the schooling quality between the host and home countries.

Results also show that cross-country differences in schooling quality account for over 90 percent of the variation in returns to foreign-obtained schooling. The findings of this paper emphasize on the importance of controlling for source quality of human capital when evaluating the economic integration of immigrants. "Quantity of schooling alone is misleading", it is important to account for quality too (Behrman and Birdsall, 1983).

One potential limitation of the current study is the omission of some relevant variables that may account for the cross-country differences in schooling returns. For instance, different schooling distributions may also generate differences in returns to education if returns are non-linear, even with the same quality of schooling, and immigrants are selected into different segments of the schooling distributions in their home countries. Due to the lack of data about schooling distribution in different countries, this was not fully captured. However, the inclusion of the country-specific fixed effects in the regression equation may partly have helped to account for these cross-country differences in schooling distribution. This paper tried to control for the influences of a number of earnings determinants to pin down the country of origin specific school returns and focus on the variations that are caused by differences in schooling quality across countries. Another limitation is the cross sectional nature of the census which limits the ability to make causal inferences. In addition, further empirical evidence from other countries and using longitudinal data will be needed before reaching a generalized conclusion. In spite of these limitations, the current study is among the first to control for cross-country differences in schooling quality by explicitly deriving a set of quality adjustment indices and applying them to an over-education exercise.

\section{Endnotes}

${ }^{1}$ Over-education occurs when the educational attainment of a worker is greater than the educational requirement of the job.

${ }^{2}$ Lee and Barro (2001) estimated a schooling quality production function that relates three measures of schooling quality (dropout rates, repetition rates and test scores) to a set of parental factors and educational resources. Bratsberg and Terrell (2002) related country of origin specific return to immigrants' education in the US labor market to several schooling quality measures.

${ }^{3}$ In addition the average years of primary schooling could also reflect the education level of the teachers.

${ }^{4}$ In a related study, Bratsberg and Terrell (2002) lagged the educational quality data for 20 years.

${ }^{5}$ Here, years of schooling are quality-adjusted using adjustment indices based on the predicted returns to schooling obtained from the quality production function.

${ }^{6}$ For additional information on the 2001 Canadian Census see Statistic Canada (2003). 
${ }^{7}$ The fact that immigrants are on average more educated than their Canadian counterparts may be due to the immigration point system which rewards education highly with up to 25 points.

${ }^{8}$ Czechoslovakia includes immigrants from both Czech Republic and Slovak Republic. ${ }^{9}$ Data on per-capita real GDP is obtained from the Penn World Tables (Heston et al., 2011).

${ }^{10}$ Dropout rates are defined as the percentage of students who started primary schools but did not attain the final grade of primary schools.

${ }^{11}$ Average years in school is also used in the literature as a measure of family background.

${ }^{12}$ In another specification, the earnings function was re-estimated with cluster robust standard errors by country of origin to account for the fact that the predicted qualityadjusted years of schooling is obtained using a different number of observations and the results were similar to those reported in the manuscript.

\section{Competing interests}

The IZA Journal of Migration is committed to the IZA Guiding Principles of Research Integrity. The author declares that he has observed these principles.

\section{Acknowledgements}

This paper uses Statistics Canada confidential data, and the opinions expressed do not represent the views of Statistics Canada. I would like to thank an anonymous reviewer as well as the managing editor of this journal for the valuable comments and suggestion. The usual disclaimer applies.

Responsible editor: Corrado Giulietti

Received: 17 April 2013 Accepted: 18 July 2013

Published: 02 Aug 2013

\section{References}

Alboim N, Finnie R, Meng R (2005) The discounting of immigrants' skills in Canada. IRPP choices 11(2)

Baker M, Benjamin D (1994) The performance of immigrants in the Canadian labor market. Journal of Labor Economics 12(3):369-405

Barro RJ, Lee JW (2010) Education attainment for population aged 15 and over 1950-2010. Available at. http://www. barrolee.com/data/yrsch.htm

Beggs JJ, Chapman BJ (1988) Immigrant wage adjustment in Australia cross-section and time-series estimation. Economic Record 64(186):161-167

Behrman JR, Birdsall N (1983) The quality of schooling: quantity alone is misleading. American Economic Review 73(5):928-946

Betts JR, Lofstrom M (2000) The educational attainment of immigrants: trends and implications. In: Borjas GJ (ed) Issues in the economics of immigration. University of Chicago Press, pp 51-117

Betts JR (1995) Does school quality matter? Evidence from the national longitudinal survey of youth. The Review of Economics and Statistics 77(2):231-250

Bratsberg B, Terrell D (2002) School quality and returns to education of U.S. immigrants. Economic Inquiry 40(2):177-198

Card D, Krueger AB (1992) Does school quality matter? Returns to education and the characteristics of public schools in the United States. Journal of Political Economy 100(1):1-40

Chiswick BR (1978) The effect of Americanization on the earnings of foreign-born men. Journal of Political Economy 86(5):897-921

Chiswick BR, Miller PW (2008) Why is the payoff to schooling smaller for immigrants? Labor Economics 15(6):1317-1340

Chiswick BR, Miller PW (2009) The international transferability of immigrants' human capital. Economics of Education Review 28(2):162-169

Chiswick BR, Miller PW (2010) Chapter 4 the effects of school quality in the origin on the payoff to schooling for immigrants. In: Epstein GS, Gang IN (eds) Migration and culture (frontiers of economics and globalization), volume 8. Emerald Group Publishing Limited, pp 67-103

Duleep HO, Regets MC (1999) Immigrants and human-capital investment. The American Economic Review 89(2):186-191

Ferrer AM, Riddell WC (2008) Education, credentials, and immigrant earnings. Canadian Journal of Economics 41(1):186-216

Friedberg RM (2000) You can't take it with you? Immigrant assimilation and the portability of human capital. Journal of labor economics 18(2):221-251

Galarneau D, Morissette R (2004) Immigrants: settling for less? Perspectives on labour and income. Statistics Canada Catalogue no. 75-001-XIE 5(6):5-16

Galarneau D, Morissette R (2008) Immigrants education and required Job skills. Perspectives on labour and income. Statistics Canada Catalogue no75-001-X 
Green C, Kler P, Leeves G (2007) Immigrant overeducation: evidence from recent arrivals to Australia. Economics of Education Review 26:420-432

Hanushek EA, Kimko DD (2000) Schooling, labor-force quality, and the growth of nations. American Economic Review 90(5):1184-1208

Hanushek EA, Woessmann L (2012) Do better schools lead to more growth? Cognitive skills, economic outcomes, and causation. Journal of Economic Growth 17(4):267-321

Hartog J (2000) Over-education and earnings: where are we, where should we go? Economics of Education Review 19(2):131-147

Hendricks L (2002) How important is human capital for development? Evidence from immigrant earnings. American Economic Review 92(1):198-219

Heston A, Summers R, Aten B (2011) Penn world table version 7.0. Center for international comparisons of production. Income and Prices at the University of Pennsylvania

Kler P (2007) A panel data investigation into over-education among tertiary educated Australian immigrants. Journal of Economic Studies 34(3): 179-193.

Ladd H, Loeb S (2012) The challenges of measuring school quality: implications for educational equity. In: Allen D, Reich R (eds) Education, justice, and democracy. University of Chicago Press, Chicago, IL, pp 22-55

Lee JW, Barro RJ (1997) Schooling quality in a cross section of countries. NBER working paper No. 6198

Lee JW, Barro RJ (2001) Schooling quality in a cross-section of countries. Economica 68:465-488

Li C, Gervais G, Duval A (2006) The dynamics of over qualification: Canada's underemployed university graduates. Statistics Canada analytical paper, Catalogue no. 11-621-MIE -No. 039

Lindley JK, Lenton P (2006) The over-education of UK immigrants: evidence from the labour force survey. Sheffield Economic Research Paper Series SERP Number: 2006001

Mattoo A, Neagu IC, Özden C (2008) Brain waste? Educated immigrants in the US labor market. Journal of Development Economics 87:255-269

Nielsen CP (2011) Immigrant over-education: evidence from Denmark. Journal of Population Economics 24:499-520

Nordin M (2011) Immigrants' returns to schooling in Sweden. International Migration 49(4):144-166

Psacharopoulos G, Woodhall M (1985) Education for development: an analysis of investment choices. Oxford University Press for the World Bank

Piracha M, Tani M, Vadean F (2012) Immigrant over-and under-education: the role of home country labour market experience. IZA Journal of Migration 1(1):1-21

Reitz JG (2001) Immigrant skill utilization in the Canadian labour market: implications of human capital research. Journal of International Migration and Integration 2(3):347-378..

Schoellman T (2012) Education quality and development accounting. The Review of Economic Studies 79(1):388-417

Sharaf MF (2013) Job-education mismatch and its impact on the earnings of immigrants: evidence from recent arrivals to Canada. ISRN Economics vol. 2013, Article ID 452358, doi:10.1155/2013/452358

Shields MA, Price SW (1998) The earnings of male immigrants in England: evidence from the quarterly LFS. Applied Economics 30:1157-1168

Statistic Canada (2003) 2001 Census handbook., Catalogue No.92-379-XIE. Available at. http://www12.statcan.ca/english/ census01/Products/Reference/2001 handbook/pdf/92-379-XIE02001.pdf

Sweetman A (2004) Immigrant source country educational quality and Canadian labor market outcomes. Analytical Studies Branch Research Paper No. 234, Statistics Canada

Wald S, Fang T (2008) Overeducated immigrants in the Canadian labour market: Evidence from the workplace and employee survey. Canadian Public Policy 34(4):457-479

10.1186/2193-9039-2-13

Cite this article as: Sharaf: The earnings of immigrants and the quality adjustment of immigrant human capital. IZA Journal of Migration 2013, 2:13

\section{Submit your manuscript to a SpringerOpen ${ }^{\circ}$ journal and benefit from:}

- Convenient online submission

- Rigorous peer review

- Immediate publication on acceptance

- Open access: articles freely available online

- High visibility within the field

- Retaining the copyright to your article

Submit your next manuscript at $\boldsymbol{\nabla}$ springeropen.com 